\title{
Menggagas Kampung Inggris Padang menjadi Kampung Inggris Masyarakat
}

\author{
Genta Sakti \\ Institut Agama Islam Negeri (IAIN) Bukittinggi, Indonesia \\ E-mail:gentasakti@gmail.com
}

2021 by the authors. Submitted for possible open access publication under the terms and conditions of the Creative Commons Attribution-ShareAlike 4.0 International License-(CC-BY-SA) (https://creativecommons.org/licenses/by-sa/4.0/) do) DOI: $\underline{\text { http://dx.doi.org/10.30983/dedikasia.vlil.4984 }}$

\begin{tabular}{l}
\hline ARTICLE INFO \\
\hline Submit : \\
Revised : \\
Accepted : \\
Keywords: Inniatition, English Camp, \\
Courses
\end{tabular}

International License-(CC-BY-SA)

(https://creativecommons.org/licenses/by-sa/4.0/)

do: $\underline{\text { http://dx.doi.org/10.30983/dedikasia.vlil.4984 }}$

\begin{abstract}
The aim of this social service is to initiate an English camp in Padang to become an English Camp Village like other famous English camps. This English camp is still in the form of an English course where many students come here to study English for some purposes like to prepare to continue to under graduate degree; to get a job or to pass TOEFL test. As its name suggest, an English camp is not merely Englishmen who live there, but it is only a collection of English courses located in one area. Since there are students coming here to study so that the researcher names this course Kampung Inggris Padang. Based on the initiation carried out for this social service, it was found that there is improvement of students' ability in speaking English like doing corversation or dialogue and reading aloud English textbook. If it is viewed from the participation of society, there are participations of people around the course like sharing ideas, skill, energy, social participation for better future of Padang English Camp. The prominece is that the realizing and caring of people about their children's education.
\end{abstract}

This is an open access article under the CC-BY-SA license

\section{Pendahuluan}

"Kampung Inggris" atau yang biasa disebut "English Camp" dalam pengabdian ini berada di daerah Andalas Padang yang termasuk dalam daerah administratif di Jalan Andalas No.20, Anduring, Kuranji, Kota Padang, Sumatera Barat. Penamaan “Kampung Inggris” bukan merujuk pada komunitas orang Inggris, seperti halnya penamaan Kampung Cina bagi komunitas etnis Cina namun biasanya untuk mengacu pada keberadaan lembaga kursus bahasa Inggris yang berjumlah lebih dari satu lembaga yang berkumpul dalam suatu wilayah yang kemudian dinamakan sebagai "Kampung Inggris".

Para peserta yang mengikuti kursus berasal dari berbagai level pendidikan di daerah kota Padang. Mereka datang ke "Kampung Inggris" khusus untuk belajar bahasa Inggris. Para peserta umumnya berstatus fresh graduate dari SMA atau sarjana strata satu (S1). Para peserta yang lulus SMA umumnya beralasan belajar bahasa Inggris untuk mempersiapkan diri melanjutkan pendidikan ke jenjang perguruan tinggi atau bekal mencari kerja. Mereka menunda melanjutkan pendidikan formal karena faktor kesengajaan atau tidak lolos seleksi penerimaan mahasiswa baru di perguruan tinggi. Waktu senggang selama satu tahun digunakan untuk belajar bahasa Inggris. Sementara para peserta dengan status lulus Sl umumnya beralasan sembari mencari pekerjaan, mereka belajar bahasa Inggris. 
Selain para freshgraduate, banyak peserta kursus masih berstatus mahasiswa Pascasarjana atau S2. Mereka datang ke "Kampung Inggris" untuk belajar TOEFL dan mengikuti test untuk syarat wisuda.

Sistem pembelajaran yang umum diterapkan secara bebas memilih paket setiap bulannya tergantung kebutuhan. Satu paket berisi program berdurasi 2 minggu sampai 1 bulan. Program yang ditawarkan, antara lain kelas grammar, listening, speaking, translation, writing, vocabulary, TOEFL, dan lainlain. Selain kelas reguler, pada masa liburan sekolah diadakan paket belajar yang mencakup keseluruhan program dengan alokasi waktu berdasarkan kesepakatan. Program liburan dirancang khusus bagi peserta untuk mengisi liburan sekolah.

Sebenarnya, pelabelan "Kampung Inggris", tidak khas berlaku di Padang ini karena baru berbentuk lembaga kursus. Namun sudah nampak geliat warga yang butuh dan mau di belajar menggunakan Bahasa Inggris dikarenakan latar belakang pendidikan. Kebanyakan warga Andalas selain penduduk asli lebih banyak mahasiswa-mahasiswa dari berbabagai univeristas, seperti UNAND, UIN Imam Bonjol Padang, Baiturrahamah maupun kampus kesehatan lainnya. Berbeda dengan Kampung Inggris Padang, Lawang mendapat julukan "Kampung Inggris" yang diresmikan oleh Bupati Indra Catri terpampang tulisan "Welcome to Kampung Inggris Lawang”. Selain itu, di Lasi Agam juga ada persiapan pendirian "Kampung Inggris" di lokasi-lokasi wisata yang diasumsikan ramai turis berkunjung.

Untuk mencapai itu semua dibutuhkan campur tangan pemerintah dan partisipasi masyarakat dalam Kursus Bahasa Inggris sebagai upaya mewujudkan Kampung Inggris. Dapat dijelaskan bahwa kebutuhan pendidikan masyarakat berkaitan erat dengan kebutuhan akan kesempatan sebaik-baiknya untuk mengembangkan diri sehingga dapat bergabung dengan dunia yang kian hari semakin berkembang. Salah satu upaya tersebut adalah melalui penguasaan bahasa yang didapatkan melalui Kursus Bahasa Inggris.

Masyarakat yang menyadari akan kebutuhan belajarnya tersebut memiliki kemandirian dan kewenangan untuk menentukan nasib pendidikannya sendiri melalui pendidikan yang dikelola sendiri oleh masyarakat. Selain itu, karena karena globalisasi saat ini bergerak sangat massif sehingga dunia menjadi seragam tanpa batas dan sekat, interaksi seseorang dengan orang lainnya dapat dilakukan dalam waktu bersamaan meski berada di jarak yang sangat jauh. Tidak terkecuali dengan batasan bahasa, bahasa Inggris yang mendominasi bahasa dunia telah menjadi penghubung interaksi tersebut.

Melihat pentingnya Bahasa Inggris sebagai bahasa interaksi internasional, tentu saja masyarakat yang berorientasi global akan berlomba-lomba untuk menguasai bahasa ini secara optimal sehingga akan terbentuk Kampung Inggris dengan bermunculan lembaga-lembaga kursus bahasa Inggris.

Untuk mencapai tujuan tersebut, belajar bahasa yang paling efektif adalah dengan melakukan praktik langsung dengan berinteraksi dalam Bahasa Inggris, tentu saja hal tersebut menjadi kesulitan tersendiri di Indonesia yang notabene bukan bahasa utama. Kampung Ingris Pare Kediri Jawa Timur memiliki cara tersendiri dalam membelajarkan peserta didiknya. Inisiasi Kampung Inggris muncul 
pertama kali dari Mr. Kalend dari Pare, Kabupaten Kediri, Jawa Timur yang berusaha meruntuhkan mitos bahwa belajar Bahasa Inggris itu sulit. Caranya adalah dengan membangun sebuah Kampung Inggris yang di dalamnya seluruh interaksi masyarakat dilakukan dengan Bahasa Inggris. Ribuan orang telah datang ke kampung ini untuk belajar Bahasa Inggris secara intensif dan berhasil melenggang ke luar negeri. Mr. Kalend awalnya hanya memulai dengan mendirikan Basic English Course (BEC) di Pare tiga dekade silam. Cerita bermula ketika pria bernama Kalend Olsend tersebut melatih dua mahasiswa IAIN Surabaya yang ingin menghadapi ujian Bahasa Inggris. Kalend yang saat itu masih seorang santri di Pesantren Darul Falah ternyata berhasil melatih mereka hanya dalam lima hari dan lulus.

Keberhasilan dua mahasiswa itu tersebar di kalangan mahasiswa IAIN Surabaya dan banyak dari mereka akhirnya mengikuti jejak seniornya dengan belajar kepada Kalend. Promosi dari mulut ke mulut pun akhirnya menjadi awal terbentuknya kelas pertama. Pada 15 Juni 1977, BEC akhirnya resmi didirikan. Seiring banyaknya murid Mr. Kalend yang lulus, dirinya pun meminta beberapa muridnya untuk membantunya dengan mendirikan lembaga-lembaga kursus baru di kampung tempat BEC berdiri. Semakin lama jumlah lembaga kursus Bahasa Inggris disana pun bertambah banyak dan jumlahnya dapat mencapai 200 lembaga. Sejak saat itulah Pare kemudian dikenal memiliki Kampung Inggris yang kemudian banyak ditilik orang untuk mengadopsi bahan dan metode belajar Kampung Inggris Pare.

\section{Metode pelaksanaan}

Pelaksanaan kegiatan pengabdian masyarakat ini dengan menggunakan metode pengabdian masyarakat berbasis riset dengan cara melakukan penelitian lebih awal terlebih dahulu sebelum melaksanakan pengabdian. Hasil dari riset awal walaupun secara sederhana, namun hasil riset awal itulah yang menjadi dasar atau berpijaknya kegiatan masyarakat yang dilakukan.

\section{Bentuk Kegiatan Selama Pengabdian}

\section{a. Survey awal}

Berdasarkan survey awal yang pengabdi lakukan selama dua hari pada tanggal 19-20 Mei 2018, Kampung Inggris Padang ini masih berbentuk Lembaga Kursus Bahasa Inggris di kota Padang, Sumbar, dengan berbagai program pilihan yaitu English for Beginners, English for Communication, General English, TOEFL, dan Intensive Class. Awalnya kursus ini beralamat di jalan Pekanbaru No.21 Ulak Karang Kota Padang, namun ketika pengabdi melakukan pengabdian, lembaga kursus ini sudah pindah alamat ke Jalan Andalas No.20, Anduring, Kuranji, Kota Padang, Sumatera Barat. Berikut dokumentasi surver awal pengabdi: 


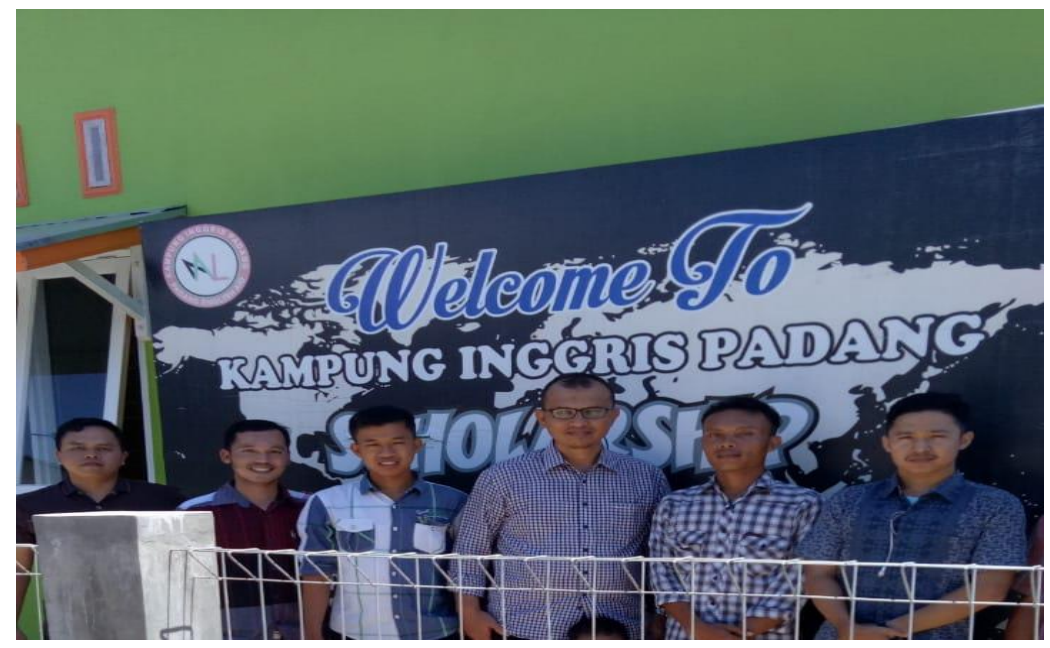

Gambar 1

Observasi lokasi dan Penggalian Informasi

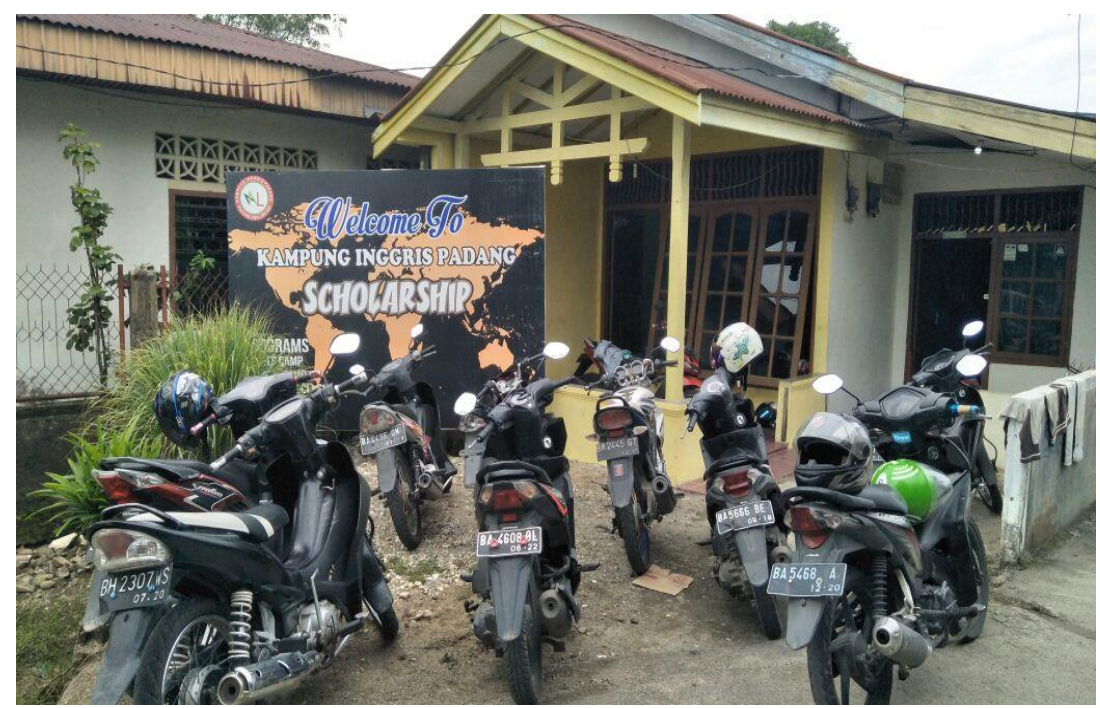

Gambar 2

Lokasi Pengabdian Masyarakat 


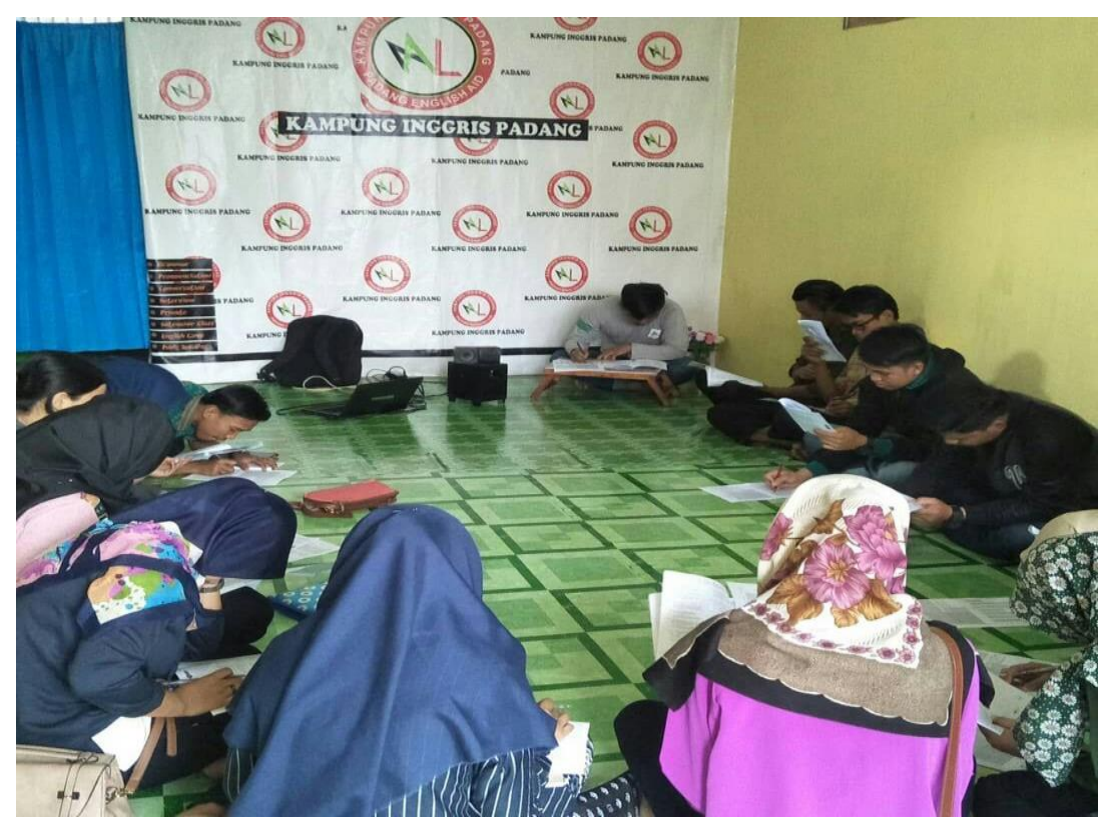

Gambar 3

\section{Observasi kegiatan Pembelajaran}

Berdasarkan gambar, terdapat belasan pembelajar bahasa Inggris di kampung Inggris Padang dengan tujuan untuk dapat memiliki sertifikat TOEFL. Mereka tergabung dalam program TOEFL yang berguna untuk syarat wisuda di kampus yang mereka ikuti. Dilihat dari kelas ekonomi, mereka yang tergabung memiliki kendaraan motor roda dua yang mengindikasikan mereka dari keluarga mampu atau menengah ke atas.

\section{b. Kegiatan Pelaksanaan}

Penggasan kampung Inggris ini dilaksanakan melalui kegiatan:

1. Ceramah dan diskusi. Metode ini merupakan pengantar pada kegiatan inti. Dalam kegiatan ini peserta diajak untuk mengenal dan mempelajari bahasa Inggris serta menggunakannya dalam kehidupan sehari-hari. (bahasa komunikasi)

2. Latihan terbimbing dalam menerapkan receptive and productive skills bahasa Inggris, speaking, reading.

3. Praktek berbicara bahasa Inggris seecara mandiri oleh peserta. Dari kegiatan ini peserta akan memperoleh pengalaman langsung penggunaan bahasa Inggris dalam kehidupan nyata. Dari kegiatan ini juga akan terlihat kesulitan-kesulitan apa yang mereka hadapi dalam belajar bahasa Ingris tersebut sehingga dapat langsung dicarikan pemecahan masalahnya. 
Jadwal pelaksanaan pengabdian menggagas kampung Inggris padang

\begin{tabular}{|c|l|c|c|c|c|}
\hline No & \multicolumn{1}{|c|}{ Kegiatan } & Hari/ tanggal & Pukul & $\begin{array}{c}\text { Juml } \\
\text { ah } \\
\text { jam }\end{array}$ & Nara sumber \\
\hline 1 & Pembukaan acara & $\begin{array}{c}\text { Selasa/ 14 } \\
\text { Agustus 2018 }\end{array}$ & $13.30-14.00$ & $\begin{array}{l}\text { Drs. Genta } \\
\text { Sakti, M.A }\end{array}$ \\
\hline 2 & $\begin{array}{l}\text { Pemberian motivasi dan } \\
\text { arahan bagaimana cara } \\
\text { menyenangkan belajar } \\
\text { bahasa Inggris dan test } \\
\text { kemampuan awal } \\
\text { bahasa Inggris. }\end{array}$ & $\begin{array}{c}\text { Selasa/ 14 } \\
\text { Agustus 2018, }\end{array}$ & $14.00-17.00$ & 3 & $\begin{array}{c}\text { Rahma } \\
\text { Mustika Sari, } \\
\text { M.Pd }\end{array}$ \\
\hline 3 & $\begin{array}{l}\text { Pelatihan dua skills } \\
\text { bahasa Inggris, Reading } \\
\text { danSpeaking }\end{array}$ & $\begin{array}{c}\text { Rabu/ 15 } \\
\text { Agustus 2018, }\end{array}$ & $\begin{array}{c}8.00-12.00 \\
14.00-16.00\end{array}$ & 5 & $\begin{array}{c}\text { Rahma } \\
\text { Mustika Sari, } \\
\text { M.Pd }\end{array}$ \\
\hline 4 & $\begin{array}{l}\text { Praktik menggunakan } \\
\text { bahasa Inggris dalam } \\
\text { berbicara. } \\
\text { Post-test }\end{array}$ & $\begin{array}{c}\text { Kamis/ 16 } \\
\text { Agustus 2018, }\end{array}$ & $8.00-12.00$ & 4 & $\begin{array}{c}\text { Rahma } \\
\text { Mustika Sari, } \\
\text { M.Pd }\end{array}$ \\
\hline 5 & $\begin{array}{l}\text { Penutupan } \\
\text { Jumlah Jam Kegiatan }\end{array}$ & $\begin{array}{l}\text { Kamis/ 16 } \\
\text { Agustus 2018, }\end{array}$ & $12.00-12.30$ & & $\begin{array}{l}\text { Drs. Genta } \\
\text { Sakti, M.A }\end{array}$ \\
\hline
\end{tabular}

\section{c. Ekspose Hasil Pengabdian}

Ekspose hasil diperlukan guna dapat mengetahui sampai sejauh mana kegiatan ini berjalan sesuai dengan target dan luaran yang ingin dicapai. Dari ekspose hasil yang di laksanakan selama satu hari, yakni tanggal 1 September 2018 diperoleh hasil kegiatan penggagasan kampung Inggris sebagai berikut:

1. Pelaksanaan kegiatan pelatihan ini selain meningkatkan kemampuan dan kemauan pembelajar berbahasa Inggris untuk belajar yang baik dan benar (mendapat ilmu) dan juga menyenangkan jiwa raga mereka karena mendapat uang saku, transaor dan makan gratis.

2. Kegiatan pelatihan ini mendapatkan tanggapan yang positif dari pemilik kampung Inggris untuk sharing ilmu terkait dengan teori pengajaran bahasa Inggris yang up to date dengan pengabdi walaupun pendiri lembaga ini sudah belajar langsung ke kampung Inggris Pare. 


\section{d. Pelaporan hasil kegiatan}

Penyusunan pelaporan hasil kegiatan penggagasan kampung Inggris untuk tahap awal sudah selesai dilaksanakan. Pelaksanaan pengabdian pun juga sudah selesai sampai expose hasil. Langkah selajuntnya pelaporan hasil kegiatan. Penyusunan pelaporan hasil kegiatan ini sudah dirampungkan.

\section{Hasil}

Seperti disinggung sebelumnya, waktu survey awal pengabdi tanggal 19-20 Mei 2018, lembaga kursus Kampung Inggris masih berada di Jalan Pekanbaru No.21 Ulak Karang Kota Padang dengan jumlah siswa yang cukup ramai. Namun ketika pengabdi melakukan pengabdian, lembaga kursus ini pindah alamat ke Jalan Andalas No.20, Anduring, Kuranji, Kota Padang, Sumatera Barat sehingga terjadi dinamika perubahan jumlah peserta pembelajar karena factor perpindahan lokasi dan juga informasi. Hal tersebut menjadi tantangan pengabdi untuk menginisiasi pengabdi untuk menjadi fasiltator bagi lembaga kursus Kampung Inggris Padang. Pelaksanaan Penggasan kampung Inggris ini dilaksanakan selama tiga hari tanggal 14-16 Agustus 2018, dan diseminasi/ expose hasil pengabdian tanggal 2 September 2018, melalui kegiatan:

\section{Pengenalan dan Pemberian Motivasi}

Dalam kegiatan pengenalan dan pemberian motivasi ini dilakukan melalui ceramah dan diskusi. Metode ini merupakan pengantar pada kegiatan inti. Dalam kegiatan ini peserta diajak untuk mengenal dan mempelajari bahasa Inggris serta menggunakannya dalam kehidupan sehari-hari. (bahasa komunikasi). Bahasa Inggris itu menarik, mudah dan mampu membuat kita terbang ke Negara lain ketika bahasa Inggris sudah dalam genggaman kita. English is fun and interesting. Speaking dengan tema yang mudah dan familiar dengan peserta dalam rangka membangkitkan kecintaan mereka kepada bahasa Inggris. Greeting, Farewell and Introduction mengawali tema speaking peserta. Seperti contoh Good day. Great party isn't? lalu direspon dengan good day, yeah. Contoh sapaan dan respon dapat dilihat dari table berikut:

\begin{tabular}{|l|l|}
\hline Greetings & Responses \\
\hline Good morning & Good morning \\
\hline Good day & Good day \\
\hline Good afternoon & Good afternoon \\
\hline Good evening & Good evening \\
\hline Hello Ron, & Hello Ms. Rahma \\
\hline Hi Nency & Hi, Pat \\
\hline How nice to see you & Nice to see you too \\
\hline How are & Fine, thanks. And you? \\
\hline How have you been & Pretty good. \\
\hline
\end{tabular}




\begin{tabular}{|l|l|}
\hline Long time not see you. & Yeah. \\
\hline
\end{tabular}

Lalu mengakiri pertemuan atau percakapan dengan preclosings untuk menunjukkan kesopanan kita ketika berbicara dengan orang lain.

\begin{tabular}{|l|l|}
\hline Greetings & Responses \\
\hline Well, I'm afraid I have to go & Thank for your coming \\
\hline Well, it's getting late. & Maybe we can talk again. \\
\hline $\begin{array}{l}\text { Maybe we could go together } \\
\text { sometime }\end{array}$ & Sound good \\
\hline Great seeing you & Same here \\
\hline I've really got to go. & Ok. See you \\
\hline
\end{tabular}

Dengan mengetahui greetings and responses, peserta dapat melakukan praktek dengan lawan baicara. Kegiatan terasa menarik, karena pembelajar merasa ini masih mudah. Lalu diskusi dilanjutkan dengan tema days and moths, describing positions, number, describing an object, what is the time, like and dislike, daily activity, describing process, family and relative, describing person, telling experience and future plan. Semua topic secara umum dapat dikategorikan menjadi tiga kajian tense, aspect and mood yakni penggunnaan simple present seperti introduction, describing place, person, process and daily activity. Penggunaan simple past untuk telling experience dan present future untuk future plan. Peserta digiring mindset nya untuk dapat menyadari pentingnya ketiga aspect itu ketika berbicara dalam bahasa Inggris.

2. Praktek berbicara bahasa Inggris seecara mandiri dengan dialog. Dari kegiatan ini peserta akan memperoleh pengalaman langsung penggunaan bahasa Inggris dalam kehidupan nyata. Dari kegiatan ini juga akan terlihat kesulitan-kesulitan apa yang mereka hadapi dalam belajar bahasa Ingris tersebut sehingga dapat langsung dicarikan pemecahan masalahnya.

3. Membaca nyaring (reading aloud) teks-teks ringan untuk menambah background knowledge dan kosakata peserta ketika praktek berbicara. Teks tersebut dilengkapi dengan vocabulary secara langsung sehingga peserta mudah memahami teks. Tema teks diangkatkan seperti I love you, I was sleeping, mam, the phone box will not disappear, this class is the best, Hermansyah's face looked red.

4. Pemberian Posttest dilakukan setelah pemberian latihan dan praktek berbicara dan membaca nyaring. Peserta diminta untuk mendeskripsikan kegiatan setiap hari Minggu, dalam artian mereka menggunakan Simple Present. Atau pengalaman ketika pergi liburan kemaren dalam rangka melihat penggunaan Simple Past. Atau memceritakan rencana masa depan atau cita-cita mereka untuk menggali Present Future peserta. 
Dokumentasi Kegiatan Pengabdian

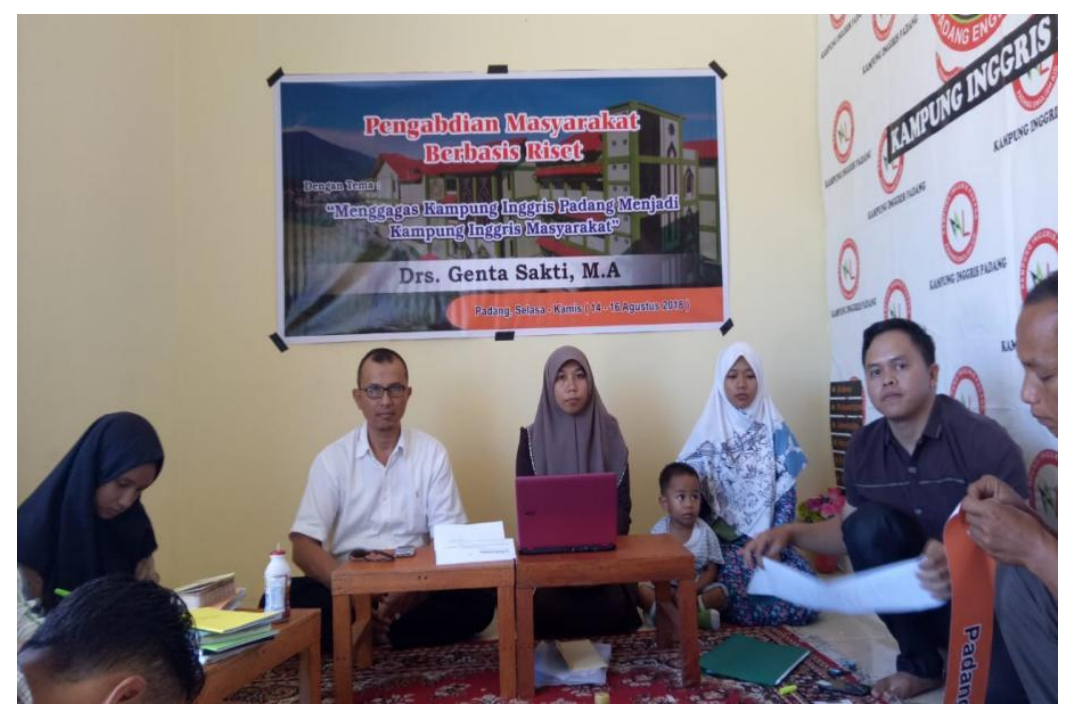

Gambar 4

Diskusi Model Pembelajaran yang akan dikembang

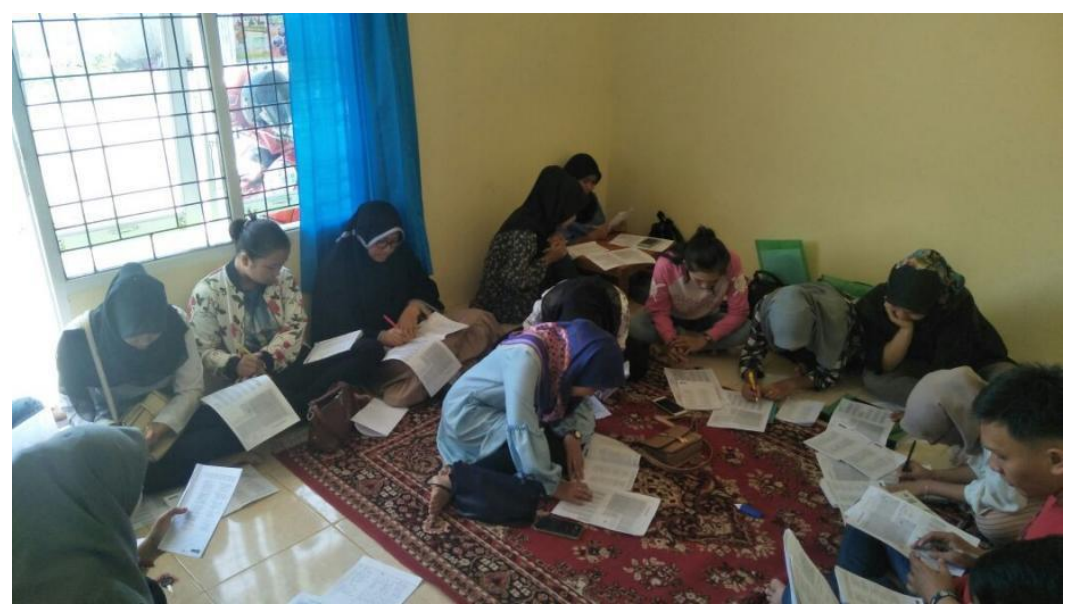

Gambar 5

Pembimbingan dan Pendampingan Pembelajaran

Kegiatan pengabdian diawali dengan pembukaan oleh tim pengabdi yang dihadiri oleh pendiri lembaga kursus Kampung Inggris Padang Rahma Mustka Sari, M.Pd. Acara diikuti oleh sepuluh peserta pengabdian. Kegiatan dilanjutkan dengan pengisian biodata peserta untuk dijadikan diinput dalam database penilaian kemampuaan awal berbicara bahasa Inggris.

\section{Kegiatan Diseminasi/ Expose Hasil Pengabdian}

Diseminasi hasil pengabdian diadakan pada tanggal 2 September 2018 dalam rangka mengeksplorasi hasil pengabdian yang telah dilakukan selama tiga hari (14-16 Agustus 2018) melalui pemberian pretest and posttest kemapuan berbicara bahasa Inggris. Dilihat dari aspek vocabulary, grammar, pronunciation, fleuncy dan comprehension. 


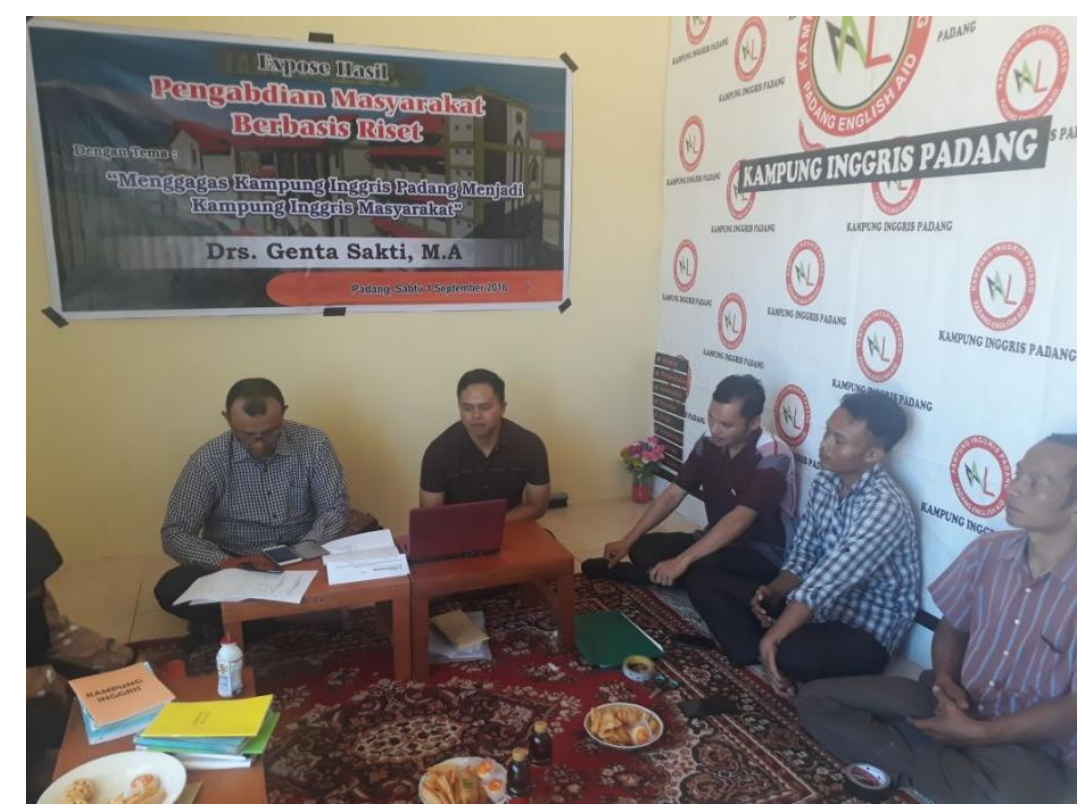

Gambar 6

Diskusi dan Pendampingan Bagi Mentor

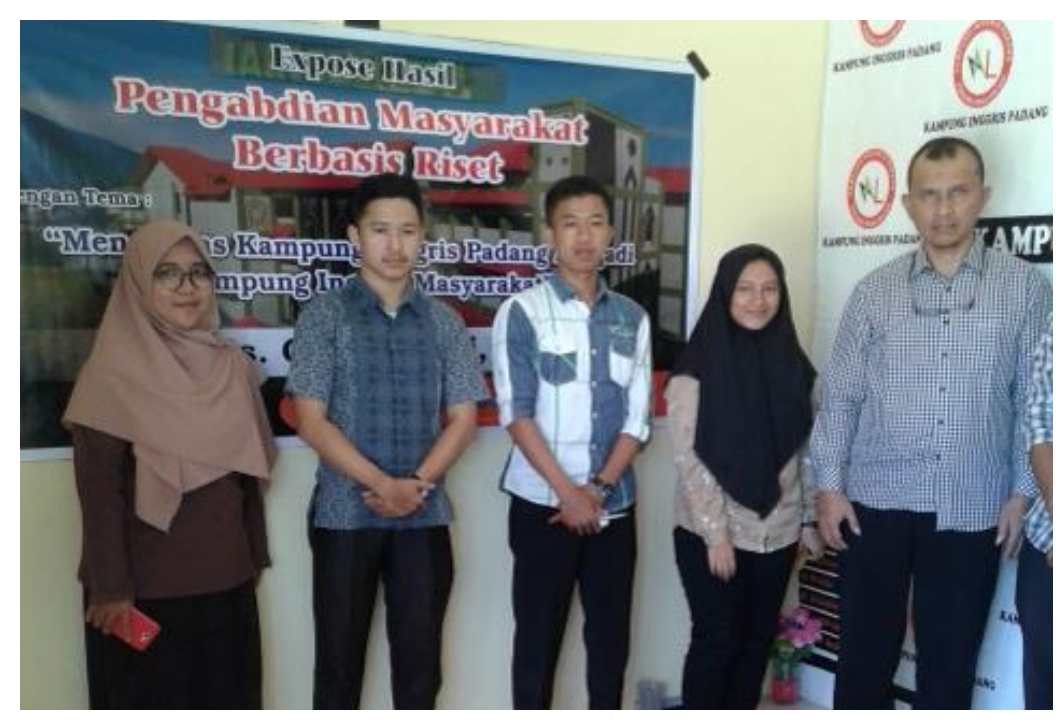

Gambar 7

Penyampaian Laporan Hasil Pendampngan 


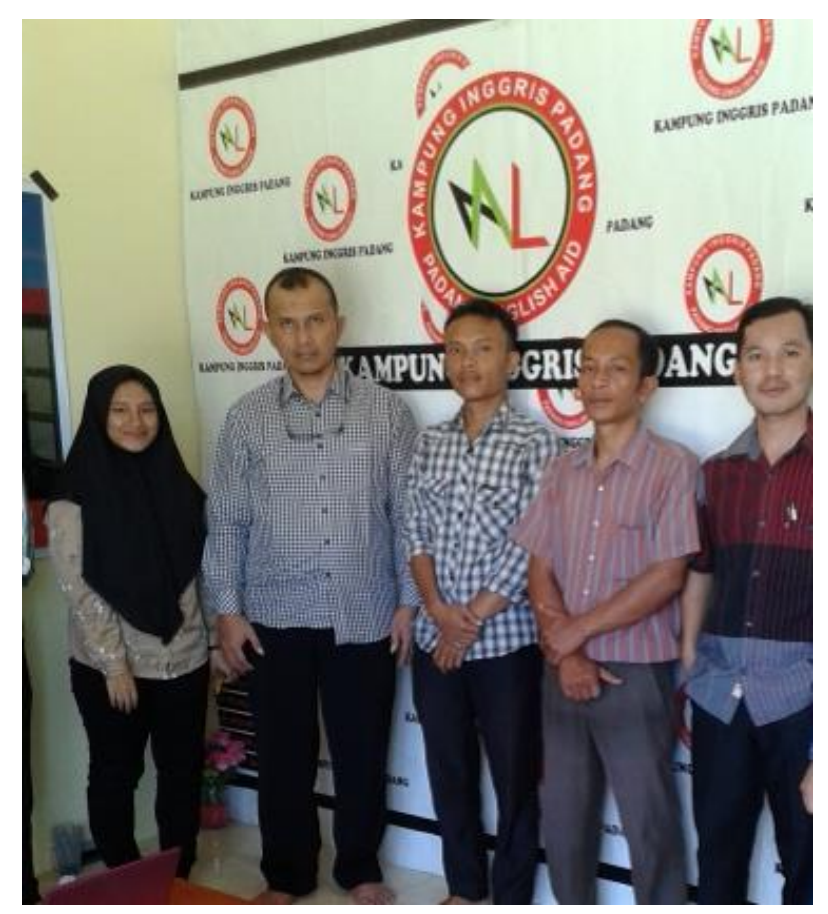

Gambar 8

Penyampaan Laporan Hasil Pendampinagn

Kegiatan diseminasi hasil.ini merupakan rangkaian terakhir dalam keseluruhan kegiatan pengabdian masyarakat dalam bentuk penggasan kampung Inggris Padang yang dilaksanakan pada tanggal 2 September 2018. Kegiatan ini bertujuan untuk membahas hasil dari kegiatan inti pengabdian yang telah dilaksanakan selama 3 hari (14-16 Agustus 2018). Kegiatan diseminasi hasil ini secara lebih rinci membahas hasil temuan dari kegiatan post-test yang dilaksanakan pada hari terakhir kegiatan inti pengabdian yaitu tanggal 16 Agustus 2018. Pada kegiatan post-test tersebut peserta diminta untuk menceritakan tentang kegiatannya setiap akhir pekan untuk melihat aspek Simple Present. Peserta diminta menceritakan pengalaman masa lalu terkait liburan akhir pecan mereka yang berarti diminta penggunaan Simple Past. Atau peserta diminta untuk menceritakan rencana masa depan mereka terkait penggunaan Present Future. Kegiatan ekspose membahas hasil dari kegiatan post-test tersebut. Dalam kegiatan diseminasi hasil ini, pengabdi menguraikan dan menjelaskan tentang kendala yang masih dihadapi para peserta dalam berbicara bahasa Inggris. Adapun hasil kegiatan ekspose tersebut meliputi:

a) Kesalahan dalam penggunaan tenses simple present, simple past dan future.

b) Kesalahan dalam penggunaan kelas kata ketika menggunakan kalimat verbal dan kalimat nominal.

c) Kelancaran berbicara yang masih rata-rata.

d) Pemahaman masih sedang.

e) Cara ucap yang masih error dalam melafazkan huruf vocal dan konsonan dalam bahasa Inggris dengan membaca sesuai dengan tulisan kata tersebut. 
Ekspose hasil diperlukan guna dapat mengetahui sampai sejauh mana kegiatan ini berjalan sesuai dengan target dan luaran yang ingin dicapai. Dari ekspose hasil yang dilaksanakan selama satu hari pada hari Minggu yakni tanggal 2 September 2018 diperoleh hasil kegiatan penggagasan kampung Inggris sebagai berikut:

1. Pelaksanaan kegiatan pelatihan ini selain meningkatkan kemampuan dan kemauan pembelajar berbahasa Inggris untuk belajar yang baik dan benar (mendapat ilmu) dan juga menyenangkan jiwa raga mereka karena mendapat uang saku, transapor dan makan gratis.

2. Kegiatan pelatihan ini mendapatkan tanggapan yang positif dari pemilik kampung Inggris untuk sharing ilmu terkait dengan teori pengajaran bahasa Inggris yang up to date dengan pengabdi walaupun pendiri lembaga ini sudah belajar langsung ke kampung Inggris Pare.

\section{Pelaporan hasil kegiatan}

Penyusunan pelaporan hasil kegiatan penggagasan kampung Inggris dilaksanakan dalam tiga tahap. Tahap awal dan tahap kedua sudah selesai dilaksanakan. Pelaksanaan pengabdian pun juga sudah selesai sampai expose hasil. Penyusunan pelaporan hasil kegiatan ini sudah dirampungkan.

\section{Strategi Pelaksanaan}

Penggasan kampung Inggris ini dilaksanakan melalui kegiatan:

1. Ceramah dan diskusi. Metode ini merupakan pengantar pada kegiatan inti. Dalam kegiatan ini peserta diajak untuk mengenal dan mempelajari Bahasa Inggris secara fun dan mdah sebagai salah satu alternatif membangkitkan motivasi siswa untuk berbahasa Inggris.

2. Praktek dan latihan terbimbing menngunakan bahsa Inggris dalam speaking dan readking a loud atau membaca nyaring. Dari kegiatan ini diharapkan peserta dapat memperoleh gambaran singkat mengenai teknik berbicara dan meningkatkan kosakata.

3. Praktek berbicara dengan monolog dan dialog secara mandiri oleh peserta. Dari kegiatan ini peserta akan memperoleh pengalaman langsung berbicara bahasa Inggris dan pengabdi memperoleh data kemampuan bahsa Inggris peserta pengabdian. Dari kegiatan ini juga akan terlihat kesulitan-kesulitan apa yang mereka hadapi dalam berbicara dan langsung dicarikan pemecahan masalahnya.

\section{Bentuk Kegiatan Selama Pengabdian}

Ada tiga rangkaian kegiatan pengabdian ini. Dimulai dari survey awal ke lembaga kursus, masyarakat sekitar Kampung Inggris dan RT tempat lembaga kursus berada. Lalu kegiatan pelaksanaan Focus Group Discussion penggagasan kampung Inggris atau pelatihannya dengan narasumber Rahma 
Mustika Sari, M.Pd yang terlebih dahulu diawali dengan pembahsan materi pengabdian melalui rapat penyiapan materi oleh tim pengabdian. Berikut penjelasannya:

\section{a. Survey awal}

Berdasarkan survey awal yang pengabdi lakukan selama dua hari pada tanggal 19-20 Mei 2018, Kampung Inggris Padang ini masih berbentuk Lembaga Kursus Bahasa Inggris di kota Padang, Sumbar, dengan berbagai program pilihan yaitu English for Beginners, English for Communication, General English, TOEFL, dan Intensive Class. Awalnya kursus ini beralamat di jalan Pekanbaru No.2l Ulak Karang Kota Padang.

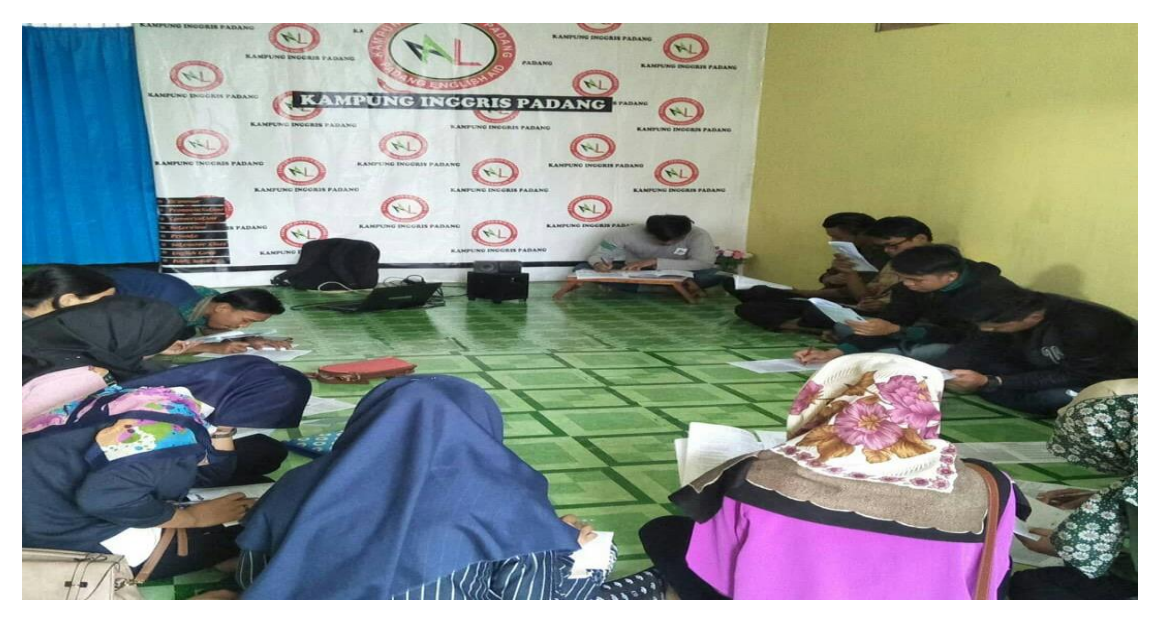

\section{Gambar 9}

\section{Suasana Pembelajaran Bahasa Inggris di Kampung Inggris Padang}

Berdasarkan gambar, terdapat belasan pembelajar bahasa Inggris di kampung Inggris Padang dengan tujuan untuk dapat memahami teks. Mereka tergabung dalam program intensif kampung Inggris yang berguna untuk meningkatkan kemampuan bahasa Inggris mereka. Dilihat dari kelas ekonomi, mereka yang tergabung memiliki kendaraan motor roda dua yang mengindikasikan mereka dari keluarga mampu atau menengah ke atas.

\section{b. Rapat Penyusunan Materi Pengabdian}

Rapat penyiapan materi pengabdian diadakan pada tanggal 4 Agustus 2018 oleh Tim Pengabdi di MTSN Ganting Padang Panjang untuk menjaring idea yang sesuai dengan materi ajar untuk masyarakat kampung Inggris. MTsn ini berpengalaman dalam membawa siswa studi banding ke kampung Iggris Pare. Jadi dari hasil rapat dengan tim dirumuskan materi ajar mencakup kemampuan dasar berbicara atau Basic Speaking yang mencakup: 


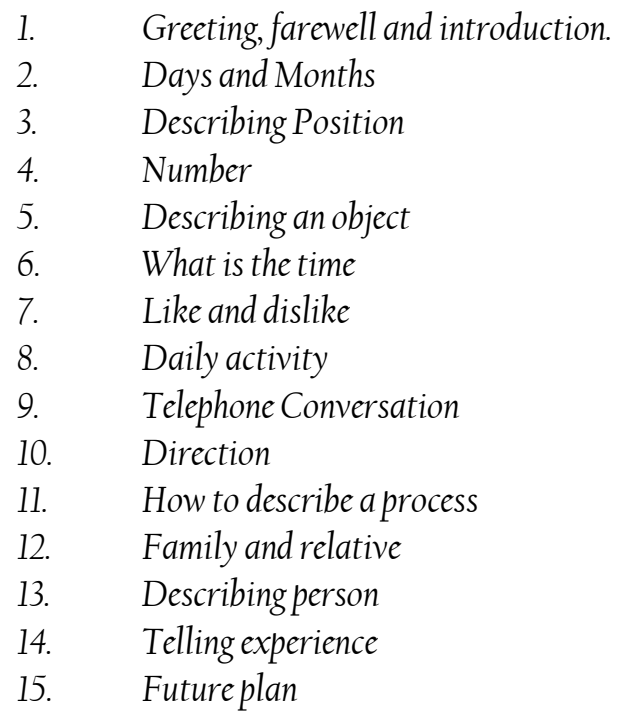

Yang secara umum dapat dikategorikan dalam tiga tenses, aspect and mode yakni Simple Present, Simple Past, and Future Tense. Dan juga materi reading sederhana yang dilengkapi dengan terjemahan vocabulary untuk meningkatkan kemampuan berbahasa Inggris siswa.

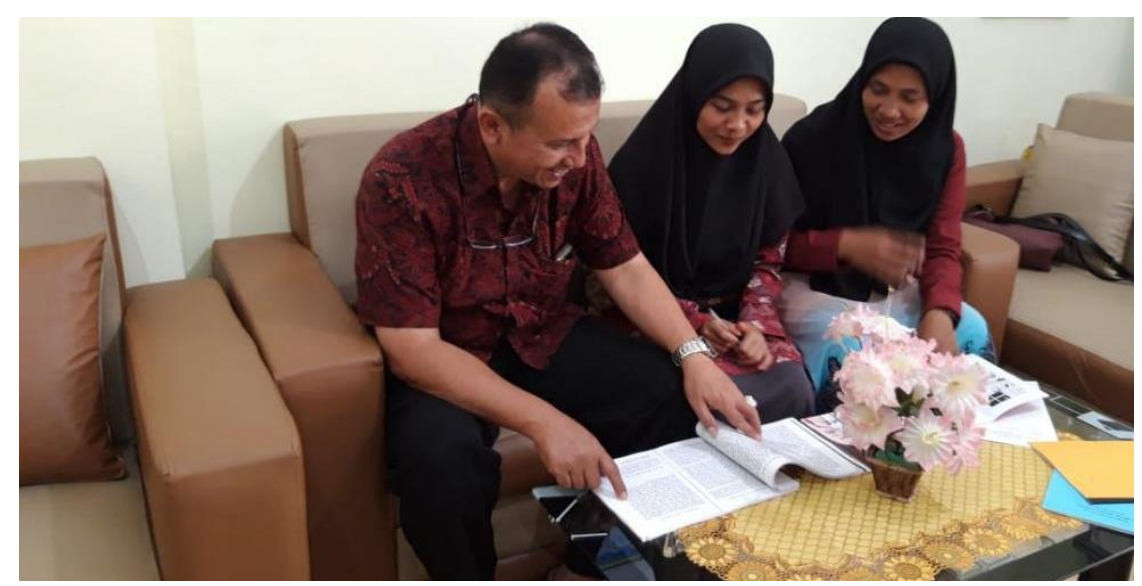

Gambar 10

Diskusi Hasil Pengabdian

\section{c. Pelaksanaan Pengabdian Menggagas Kampung Inggris}

Pelaksanaan pengbdian dilakukan selama tiga hari tanggal 14-16 Agustus 2018 bersama narasumber Rahmamustika Sari,M.Pd. kegiatan diawali dengan pembukaan dan kata sambutan dari Tim pengabdi yakni Drs. Genta Sakti, M.A. Berikut jadwal acara pengabdian:

\begin{tabular}{|c|c|c|c|c|l|}
\hline No & Kegiatan & $\begin{array}{c}\text { Hari/ } \\
\text { tanggal }\end{array}$ & Pukul & $\begin{array}{c}\text { Juml } \\
\text { ah } \\
\text { jam }\end{array}$ & $\begin{array}{c}\text { Nara } \\
\text { sumber }\end{array}$ \\
\hline 1 & Pembukaan acara & Selasa/ 14 & $13.30-$ & & Drs. \\
& & Agustus & 14.00 & & $\begin{array}{l}\text { Genta } \\
\text { Sakti, } \\
\end{array}$ \\
& & & & & M.A \\
\hline
\end{tabular}




\begin{tabular}{|c|c|c|c|c|c|}
\hline 2 & $\begin{array}{l}\text { Pemberian } \\
\text { motivasi dan } \\
\text { arahan bagaimana } \\
\text { cara } \\
\text { menyenangkan } \\
\text { belajar bahasa } \\
\text { Inggris dan test } \\
\text { kemampuan awal } \\
\text { bahasa Inggris. }\end{array}$ & $\begin{array}{l}\text { Selasa/ } 14 \\
\text { Agustus } \\
2018\end{array}$ & $\begin{array}{c}14.00 \\
17.00\end{array}$ & 3 & $\begin{array}{l}\text { Rahma } \\
\text { Mustika } \\
\text { Sari, } \\
\text { M.Pd }\end{array}$ \\
\hline 3 & $\begin{array}{lr}\text { Pelatihan } & \text { dua } \\
\text { skills } & \text { bahasa } \\
\text { Inggris, } & \text { Reading } \\
\text { dan Speaking }\end{array}$ & $\begin{array}{l}\text { Rabu/ } 15 \\
\text { Agustus } \\
2018\end{array}$ & $\begin{array}{c}8.00-12.00 \\
14.00- \\
16.00\end{array}$ & 5 & $\begin{array}{c}\text { Rahma } \\
\text { Mustika } \\
\text { Sari, } \\
\text { M.Pd }\end{array}$ \\
\hline 4 & $\begin{array}{l}\text { Praktik } \\
\text { menggunakan } \\
\text { bahasa Inggris } \\
\text { dalam berbicara. } \\
\text { Post-test }\end{array}$ & $\begin{array}{l}\text { Kamis/16 } \\
\text { Agustus } \\
2018\end{array}$ & $\begin{array}{l}8.00- \\
12.00\end{array}$ & 4 & $\begin{array}{l}\text { Rahma } \\
\text { Mustika } \\
\text { Sari, } \\
\text { M.Pd }\end{array}$ \\
\hline 5 & Penutupan & $\begin{array}{l}\text { Kamis/ } 16 \\
\text { Agustus } \\
2018\end{array}$ & $\begin{array}{c}12.00 \\
12.30\end{array}$ & & $\begin{array}{l}\text { Drs. } \\
\text { Genta } \\
\text { Sakti, } \\
\text { M.A }\end{array}$ \\
\hline \multicolumn{3}{|c|}{ Jumlah Jam Kegiatan } & & 12 & \\
\hline
\end{tabular}

Kegiatan pengabdian dilakukan dengan pemberian materi pengadian yang lengkap yakni buku English basic speaking dan buku Fun English Reading untuk semua peserta agartetap belajar otodidak ke depannya.

\section{d. Kegiatan Diseminasi/ Expose Hasil Pengabdian}

Diseminasi hasil pengabdian diadakan pada tanggal 2 September 2018 dalam rangka mengexpose hasil pengabdian yang telah dilakukan selama tiga hari (14-16 Agustus 2018) melalui pemberian pretest and posttest kemapuan berbicara bahasa Inggris.

E.

Pengabdian masyarakat yang dilakukan di lembaga kursus Kampung Inggris Padang masih diikuti oleh perserta yang terkategori siswa sekolah. Partisipasi masyarakat umum yang diperoleh dari masyarakat umum belum begitu banyak. Hal ini disebabkan karena warga yang sibuk bekerja sebagai pegawai dan beberapa petani dan wiarswasta. Mereka yang datang hanya anak warga yang sekolah 
yang tinggal di sekitar lembaga. Dari mereka inilah data pengabdian ini dipeoleh yakni dari test kemampuan awal dan kemapuan akhir berbicara atau speaking bahasa Inggris.

\section{Analsis Data Speaking}

Kemampuan berbicara bahasa Inggris peserta pengabdian meningkat secara signifikan dengan adanya pemberian materi pelatihan. Mereka diajak membaca nyaring teks terlebih dahulu secara kontektual sehingga memperoleh kosakata dari teks tersebut. Di samping itu perserta juga dapat melihat bagaimana kosa katan dan tata bahasa yang digunakan ketika misalnya berkenalan, menceritkan kebaisaan setiap, pengalaman masa lalu dan rencana masa depan.

Berikut data hasil speaking peserta pengabdian Kampung Inggris Padang:

\section{Hasil Pretest Peserta}

\begin{tabular}{|c|c|c|c|c|c|c|c|}
\hline \multirow[b]{2}{*}{ No } & \multirow[b]{2}{*}{ Nama } & \multicolumn{5}{|c|}{ Elemen Speaking } & \multirow{2}{*}{$\frac{\text { nilai }}{\text { total skor }}$} \\
\hline & & Pro & Gra & Voc & Flue & Comp & \\
\hline 1 & $\mathrm{~F}$ & 2 & 2 & 2 & 2 & 3 & 37 \\
\hline 2 & Mas & 2 & 2 & 2 & 2 & 2 & 33 \\
\hline 3 & Mar & 3 & 3 & 2 & 3 & 2 & 43 \\
\hline 4 & MF & 3 & 2 & 2 & 3 & 3 & 43 \\
\hline 5 & YA & 3 & 3 & 2 & 3 & 2 & 43 \\
\hline 6 & MEH & 3 & 3 & 3 & 4 & 3 & 53 \\
\hline 7 & IM & 3 & 3 & 4 & 4 & 3 & 57 \\
\hline 8 & ZK & 3 & 2 & 3 & 3 & 3 & 47 \\
\hline 9 & DF & 4 & 3 & 4 & 3 & 4 & 60 \\
\hline 10 & NA & 2 & 3 & 3 & 2 & 4 & 47 \\
\hline
\end{tabular}

Berdasarka Tabel di atas, ada lima indikator yang digunakan untuk mengukur kemampuan berbicara peserta, yakni pronunciation (pengucapan), grammar (tata bahasa), vocabulary (kosakata), fluency (kelancaran), dan comprehension (pemahaman).

a. Aspek Pronunciation (Pengucapan/ pelafalan)

Umumnya peserta masih kaku dalam dan mengucapkan kata bahasa Inggris sebagai mana tertulis. Mereka pada tahap awal pemberian test berbicara ini diajak untuk mendeskripsikan diri mereka. Kesalahan dalam pronunciation terlihat dari contoh kata organization, communication yang dibaca ..tion yang harusnya ...syen. Pengucapan huruf vocal yang tidak sesuai dengan tulisannya sering menjadi kendala juga berbicara, seperti focus yang dibaca fokes. live in diucapkan laiv in. Di samping juga penggunaan intonasi yang salah, ketika intonasi bertaya intonasi menurun sehingga seperti memberi 
pernyaataan padahal memberikan pertanyaan dan begitu juga sebaliknya. Ketika memberikan informasi atau pernyataan, intonasi yang digunakan bertanya. Hal ini dinilai dari rentang nilai 1-6 dari yang menggangu makna sehingga terjadi misunderstanding atau pemahaman antar pembicara sampai yang sesuai dengan maksud ucapan.

b. Aspek grammar/ tata bahasa

Grammar yang dimaksud di sini adalah kesesuaian subject dan verb yang sering disebut SubjectVerb Agreement. Dalam kalimat verbal ketika subjek kalimat saya, kamu, kami, mereka, kata kerja tidak memakai akhiran -s atau -es. Namun ketika subjek kalimat orang ketiga tunggal seperti She, he, my car dan lain-lai, kata kerjanya wajib ditambah akhiran s-/es. Misalnya I goto school by motorcycle, but my father goes to work by car. Ketentuan tata bahasa seperti ini sering dilanggar oleh pembelajar bahasa Inggris karena ketidaktahuan ataupun lupa. Di samping itu, kalimat nominal dalam bahsa Inggris membutuhkan predicate to be. Maksudnya ketika berbicara menggunakan kata sifat, kata benda dan kata keterangan, wajib menambahkan tobe yang sesuai dengan subjeknya. Misalnya I am the younget son in the family. My mom is a beautiful woman. She is at home every day. Kesalahan yang banyak dalam berbicara yakni penghilangan tobe seprti, I busy. He hungry yang harunsya I ambusy, he is hungry. Aspek ini dinilai dari range 1-6 yang tidak berterima sampai berterima dalam bahasa Inggris.

c. Aspek Vocabulary

Keragaman kosakata yang dipakai dalam berbicara menunjukan kemampuan bahasa Inggris seseorang. Kemampuan mengubah kelas kata menjadi kelas kata yang lain juga menunjukkan kosakata seseorang baik. Pemerolehan kosakata dapat dicapai melalui pengamatan bahasa asing yang banyak digunakan dalam kehidupan sehari-hari seperti iklan televise, merk toko, aplikasi HP, dan juga berkunjung ke bandara dan tempat umum yang menggunakan bilinguals. Kesalahan yang banyak terjadi ditemukan dalam kegagalan memahami perbandingan bahasa Inggris dengan bahasa Ibu atau bahasa Indonesia. Misalnya I am forget to bring my book.

\section{d. Aspek Fluency}

Aspek kelancaran mengacu kepada kemampuan seseorang berbicara dengan level yang normal atau keberlajutan berbicara dengan tingkat dan usaha menghubungkan ide dan bahasa untuk membentuk ucapan yang koheren, atau nyambung. Kata kuncing menilai kelancarna di sini tingkat kenormalan bercerita dan keterkaitan antar ide dengan adanya penggunaan pronoun, kata hbung dll. Terkadang perserta tidak mampu berceita dengan lancar dan nyambung, Mereka ada yang lambat bercerita karena kekurangan ide dan kosakata bahasa, ada juga yang terbata-bata. Mereka yang lancer berbicara juga kurang mengindahkan tata bahasa karena yang penting bagi mereka berbunyi. Kelancaran adalah salah satu indicator penilainyang subjektif juga ketika mendenagar seseorang 
bercerita. Namun secara umum dapat disimpulkan, seseorang yang dapat berbicara dalam topic apapun dengan kelancaran seperti penutur asli itu dianggap paling tinggi nilainya.

e. Aspek Comprehension

Element speaking yang terakhir yakni pemahaman. Pemahaman itu bagaimana orang lain dapat memperoleh informasi dari yang cerita ysng disampaikan penuturnya. Dia dapat diartikan sebagai kemampuan memahami sesuatu dengan pemahaman subjek yang masuk akal atau sebagai pengetahuan tentang seperti apa atau bagaimana situasinya. Secara umum, sangat paham dinilai sangat tinggi karena dapat memahami berbagai topic pembicaraan baik dalam kontek formal maupun santai seperti penutur asli. Pemahaman termasuk indikatot berat bagi penutur non asli dalam memerikan informasi kepada lawan bicara. Lebih paham orang ketika digunakan bahasa Ibu dari bahasa Inggris sehinggan untuk menghindari gagal paham sering dilakukan alih kode atau code switching. Berikut hasil test berbicara setelah diberi pelatihan dengan indicator soal yang relative sama.

\section{Hasil Postest Peserta}

\begin{tabular}{|c|c|c|c|c|c|c|c|}
\hline \multirow[b]{2}{*}{ No } & \multirow[b]{2}{*}{ Nama } & \multicolumn{5}{|c|}{ Elemen Speaking } & \multirow{2}{*}{$\frac{\text { nilai }}{\text { total skor }}$} \\
\hline & & Pro & Gra & Voc & Flue & Comp & \\
\hline 1 & $\mathrm{~F}$ & 3 & 3 & 3 & 4 & 3 & 53 \\
\hline 2 & Mas & 3 & 3 & 4 & 4 & 4 & 60 \\
\hline 3 & Mar & 4 & 3 & 3 & 4 & 4 & 60 \\
\hline 4 & MF & 3 & 3 & 3 & 4 & 3 & 53 \\
\hline 5 & YA & 4 & 3 & 3 & 4 & 4 & 60 \\
\hline 6 & MEH & 4 & 4 & 4 & 5 & 4 & 70 \\
\hline 7 & IM & 5 & 5 & 5 & 5 & 5 & 83 \\
\hline 8 & $\overline{Z K}$ & 4 & 3 & 3 & 4 & 4 & 60 \\
\hline 9 & $\mathrm{DF}$ & 5 & 5 & 4 & 5 & 5 & 80 \\
\hline 10 & NA & 3 & 3 & 3 & 4 & 4 & 57 \\
\hline
\end{tabular}

Secara umum terjadi peningkatan hasil test berbicara dilihat dari kelima aspek sebelum dan sesudah berbicara. Dilihat secara lebih spesifik berikut analisa data dengan menggunakan SPSS20:

Rekap Kedua Nilai

\begin{tabular}{|c|l|c|c|}
\hline NO & \multicolumn{1}{|c|}{ Nama } & Nilai Prestest & Nilai Postest \\
\hline l & F & 37 & 53 \\
\hline 2 & Mas & 33 & 60 \\
\hline
\end{tabular}




\begin{tabular}{|c|l|c|c|}
\hline 3 & Mar & 43 & 60 \\
\hline 4 & MF & 43 & 53 \\
\hline 5 & YA & 43 & 60 \\
\hline 6 & MEH & 53 & 70 \\
\hline 7 & IM & 57 & 83 \\
\hline 8 & ZK & 47 & 60 \\
\hline 9 & DF & 60 & 80 \\
\hline 10 & NA & 47 & 57 \\
\hline
\end{tabular}

Uji T berpasangan yang dilakukan sebelum dan sesudah mendapat treatment pengabdian: dengan hipotesis (ha) kemampuan berbicara peserta lebih baik dari sebelum diberi pelatihan penggasan kampung Inggris. Dengan kata lain keterampilan berbicara peserta lebih baik setelah diberi pelatihan.

T-Test

Paired Samples Statistics

\begin{tabular}{|rc|r|r|r|r|}
\hline & Mean & N & Std. Deviation & \multicolumn{1}{|c|}{$\begin{array}{c}\text { Std. Error } \\
\text { Mean }\end{array}$} \\
\hline \multirow{2}{*}{ Pair l } & Pretest & 46.30 & 10 & 8.460 & 2.675 \\
& Postest & 63.60 & 10 & 10.575 & 3.344 \\
\hline
\end{tabular}

Paired Samples Correlations

\begin{tabular}{|ll|r|r|r|}
\hline & \multicolumn{1}{|c|}{$\mathrm{N}$} & Correlation & \multicolumn{1}{c|}{ Sig. } \\
\hline Pair l & Pretest \& Postest & 10 & .836 & .003 \\
\hline
\end{tabular}

Paired Samples Test

\begin{tabular}{|c|c|c|c|c|c|c|c|c|}
\hline & \multicolumn{5}{|c|}{ Paired Differences } & \multirow[t]{3}{*}{$\mathrm{t}$} & \multirow[t]{3}{*}{$\mathrm{df}$} & \multirow{3}{*}{$\begin{array}{l}\text { Sig. } \\
(2- \\
\text { tailed } \\
)\end{array}$} \\
\hline & \multirow[t]{2}{*}{$\begin{array}{l}\mathrm{Me} \\
\text { an }\end{array}$} & \multirow[t]{2}{*}{$\begin{array}{c}\text { Std. } \\
\text { Deviat } \\
\text { ion }\end{array}$} & \multirow[t]{2}{*}{$\begin{array}{l}\text { Std. } \\
\text { Error } \\
\text { Mean }\end{array}$} & \multicolumn{2}{|c|}{$\begin{array}{c}95 \% \\
\text { Confidence } \\
\text { Interval of the } \\
\text { Difference } \\
\end{array}$} & & & \\
\hline & & & & Lower & Upper & & & \\
\hline $\begin{array}{ll} & \text { Pretest } \\
\mathrm{Pa} & - \\
\text { ir } 1 & \\
& \text { Postest }\end{array}$ & $\begin{array}{r}17.3 \\
00\end{array}$ & 5.813 & 1.838 & 21.458 & -13.142 & $\begin{array}{r}9.41 \\
2\end{array}$ & 9 & .000 \\
\hline
\end{tabular}


Berdasarkan ouput hasil pengolahan SPSS20 ditemukan ada peningkatan kemampuan berbicara bahasa Inggris kemampuan bahasa Inggris dilihat dari nilai Sig 0.00 lebih kecil dari alfa 0.01. Dapat disimpulkan penggagasan kampung Inggris dengan pelatihan berbicara dan membaca nyaring dapat meningkatkan kemampuan berbicara peserta.

\section{b. Analisis Partisipasi Masyarakat}

Dilihat dari partisapasi masyarakat, pengabdi menemukan indikator partisipasi masyarakat kampung Inggris seperti dikemukakan oleh Santoso S. Hamijoyo sebagai berikut:

Partisipasi buah fikiran yaitu menyumbangkan ide/ gagasan, pendapat, pengalaman, untuk keberlangsungan suatu kegiatan. Dari sini maka akan terbentuk tujuan bersama yang hendak dicapai. Berdasarkan sejarah terbentuknya Kampung Inggris bermula dari adanya lembaga kursus kampung Inggris. Walaupun jumlah masih satu, diharapakan muncul lembaga baru dengan satu tujuan yang hendak dicapai bersama melalui sumbangan ide, pendapat, dan pengalaman. Tujuan yang hendak dicapai adalah tercipta sebuah kampung yang terdiri atas lembaga-lembaga Kursus Bahasa yang berkualitas, peka zaman, namun tidak melupakan budaya dan norma yang ada dengan tetap menjaga kehidupan yang rukun, gotong royong, dan saling menolong.

Partisipasi keterampilan, yaitu berupa pemberian skill yang ia miliki untuk perkembangan program sehingga terbentuk dorongan untuk terlibat aktif mencapai tujuan tersebut melalui keikutsertaan mereka dalam memperbaiki kualitas lembaga kursus, mengembangkan program sesuai kebutuhan masyarakat, beradaptasi menggunakan Bahasa Inggris dalam keseharian, dorongan untuk menjalin relasi yang baik dengan berbagai pihak mulai dari masyarakat sekitar dan lembaga kursus.

Partisipasi tenaga dan harta benda sehingga terbentuk keterlibatan aktif oleh masyarakat secara fisik maupun mental. Partisipasi masyarakat ini baru terlihat mengirim anaknya belajar lembaga kursus di Kampung Inggris. Partisipasi sosial yaitu keterlibatan dalam kegiatan sosial demi kepentingan bersama sehingga terbentuk tanggung jawab yang dilakukan masyarakat. Tanggung jawab yang terbentuk disana adalah dengan tetap menjaga nilai-nilai kemasyarakatan (nilai agama, sosial, kesopanan,dll) yaitu terlihat pada beberapa lembaga kursus yang menerapkan sistem pondok pesantren dan berbagai aturannya. Lalu dengan membangun infrastruktur umum yang berguna bagi kehidupan sehari-hari masyarakat.

Bentuk tangung jawab yang lain adalah dengan mendaftarkan lembaga kursus ke Dinas Pendidikan dan Kementerian Pendidikan dan Kebudayaan sehingga lembaga tersebut dinyatakan layak untuk meyelenggarakan program kampung Inggris. Menurut Surakhmad sebegai berikut:

Masyarakat memiliki kepedulian dan kepekaan mengenai pendidikan; yaitu dimulai dari berdirinya lembaga-lembaga kursus hingga saat ini sehingga menunjukkan bahwa masyarakat sangat 
peka dan peduli akan pendidikan bagi masyarakat. Masyarakat menyadari pentingnya pendidikan bagi kemajuan mereka. Hal ini tercermin dari antusiasme masyarakat Kampung Inggris untuk mengembangkan dirinya dengan mengikuti diklat kepemimpinan, diklat Bahasa Inggirs, diklat Manajemen, dan lain sebagainya sehingga nantinya ia dapat menerapkannya dalam penyelenggaraan kursus. Gejala belum terlihat karena masih anak-anak sekolah yang minat belajar di kampung Inggris.

Masyarakat mampu menentukan tujuan pendidikan yang relevan bagi mereka, yaitu pendidikan yang sesuai dengan kebutuhan masyarakat (kursus Bahasa Inggris yang disesuaikan dengan bidang-bidang tertentu seperti pelayaran, kedokteran, perhotelan, dan lain sebagainya). Kampung Inggris ini masih menyedikan English for academic purpose belum lagi English for Sprecific Purpose. Masyarakat aktif berpartisipasi di dalam penyelenggaraan pendidikan yaitu dengan keterlibatan mereka dalam kegiatan kursus secara langsung maupun tidak langsung dengan menjadi pendiri lembaga, pengelola, penyelenggara, pengajar dan peserta didik.

Masyarakat menjadi pendukung pembiayaan dan pengadaan sarana pendidikan. Sebagian besar lembaga kursus menggunakan sumber dana mandiri. Kemudian dibebankan biaya kepada peserta didik yang belajar Bahasa Inggris di Kampung Inggris, dengan begitu masyarakat secara langsung mendukung dan mengupayakan pembiayaan serta sarana prasarana pendidikan kursus Bahasa Inggris.

\section{Penutup}

Kegiatan pengabdian Penggagasan Kampung Inggris yang dilakukan sudah melibatkan warga sekitar lembaga walaupun mereka yang ikut masih anak sekolah yang memang butuh pelajaran bahasa Inggris untuk sekolahnya. Dari kegiatan pengabdian masyarakat yang dilakukan maka dapat disimpulkan terjadinya peningkatan antusiasme masyarakat dalam pembelajaran dari asusmi sulit berubah menjadi asumsi mudah dan menyenangkan dan juga terjadinya peningkatan kemampuan berbicara dalam aspek kosakata, grammar, pronunciation, fleuncy dan comprehension. 


\section{Daftar Pustaka}

Ajzen, Icek.1998. Attitudes, Personality and Behavior.Chicago: Dorsey Press.

Batubara.2010. Strategi Belajar Mengajar. Surabaya: Bina Ilmu

Brown, Douglas. 1994. Teaching by Principles: An Interactive Approach to Language Pedagogy. New Jersey: Prentice Hall Regents.

Brown, Douglas. 2007. Principles of Language Learning and Teaching. New York: Pearson Education, Inc.

Dahar, Ratna Willis. Prof. Dr. 2000. Teori-Teori Belajar. Jakarta: P2LPTK.

Donaldson Orlich. 1998. Teaching Strategies. Boston : Houghton Miffin Company.

Elhans. 2014. English Conservation 900 Pelajaran Percakapan Bahasa Inggris 900. Surabaya: Alfa

McCarthy, M. (2010). Touchstone. Cambridge: University Cambridge.

Nunan, D. (2003). Practical English Language Teaching. New York: The McGraw Hill Companies.

Nurgiantoro, Burhan. 2010. Penilaian dalam Pengajaran Bahasa dan Sastra edisi ketiga. Yogyakarta: BPFEYogyakarta.

O'Neill, Geraldine and Tim McMahon. 2005. Students-centered learning: what does it mean for students and lecturers? In Emerging Issues in the Practice of University Learning and Teaching. O'Neill, G., Moore, S., McMullin, B. (Eds). Dublin: AISHE.

Richards, C. J. (2000). New Interchange. Cambridge: University Cambridge.

Srihandayani. (2016). Pentingnya kemampuan berbahasa inggris dalam menyongsong ASEAN community 2015. Jurnal Profesi Pendidik. Vol. 3 no. 1. Hal. 102-106.

Sugiono.2006. Teori Pendidikan Praktis Bandung: Alfabeta

Sugiyono. 2011. Metode Penelitian Kuantitatif, Kualitatif, dan RÆD. Bandung: Alfabet

Sumardi Suryabrata.2008.Metodologi Penelitian. Jakarta : Raja Grafindo Persada. 